\title{
CD18/ICAM-1-dependent Oxidative NF-кB Activation Leading to Nitric Oxide Production in Rat Kupffer Cells Cocultured with Syngeneic Hepatoma Cells
}

\author{
Iwao Kurose, Hidetsugu Saito, Soichiro Miura, Hirotoshi Ebinuma, Hajime Higuchi, Naoyuki Watanabe, Shigeyuki Zeki, \\ Tetsuya Nakamura, Masaaki Takaishi, and Hiromasa Ishii \\ Department of Internal Medicine, School of Medicine, Keio University, Tokyo 160, Japan
}

\begin{abstract}
Previous studies have indicated that nitric oxide (NO) released from Kupffer cells modulates biological viability of cocultured hepatoma cells. This study was designed to evaluate the mechanisms by which Kupffer cells synthesize and release NO in reponse to cocultured hepatoma cells. Kupffer cells isolated from male Wistar rats were cocultured with rat hepatoma cell line, $\mathrm{AH} 70$ cells. The sum of nitrite and nitrate levels increased in the culture medium of Kupffer cells with AH70 cells as compared with those of Kupffer cells or AH70 cells alone. Increased expressions of iNOS and iNOS mRNA in Kupffer cells cocultured with AH70 cells were detected by an immunofluorescence staining and a fluorescence in situ hybridization study, respectively. A fluorescence in situ DNA-protein binding assay revealed that NF- $\mathrm{K}$ activation occurs in Kupffer cells and activated NF- $\mathrm{B}$ moved into the nuclei preceding to an increased production of NO. Oxidative stress indicated by dichlorofluorescein fluorescence was observed in Kupffer cells cocultured with AH70 cells. An increased calcium mobilization indicated as increased fluo3-associated fluorescence was also induced in Kupffer cells after coculture with AH70 cells. Monoclonal antibodies directed against rat CD18 and ICAM-1, as well as TMB-8, a calcium inhibitor, prevented the calcium mobilization, active oxygen production, and $\mathrm{NF}-\kappa \mathrm{B}$ activation in addition to the increased production of NO. Pyrrolidine dithiocarbamate, an inhibitor of oxidative NF- $\mathrm{B}$ activation, diphenylene iodonium, an NADPH oxidase inhibitor, and quinacrine, a phospholipase $A_{2}$ inhibitor, significantly attenuated the increase in dichlorofluorescein fluorescence, NF-кB activation, and NO production. Therefore, this study suggests that CD18/ICAM-1-dependent cell-to-cell interaction with hepatoma cells causes calcium mobilization and oxidative activation of NF- $\kappa \mathrm{B}$, which may lead to the increased production of NO in Kupffer cells. (J. Clin. Invest. 1977. 99: 867-878.) Key words: laser scanning confocal microscopy • mRNA fluorescence in situ hybridization - fluorescence in situ DNA-protein binding assay - dichlorofluorescein • fluo-3
\end{abstract}

\footnotetext{
Address correspondence to Iwao Kurose, M.D., FAX: 81-3-33536247, and reprint requests to Hiromasa Ishii, M.D., Professor and Head, Department of Internal Medicine, School of Medicine, Keio University, 35 Shinanomachi, Shinjuku-ku, Tokyo 160, Japan. Phone: 81-3-3353-1211 x2260; FAX: 81-3-3356-9654.

Received for publication 18 September 1996 and accepted in revised form 6 December 1996.
}

J. Clin. Invest.

(C) The American Society for Clinical Investigation, Inc.

0021-9738/97/03/0867/12 \$2.00

Volume 99, Number 5, March 1997, 867-878

\section{Introduction}

Activated macrophages have the capacity to recognize and destroy neoplastic cells. To eradicate individual tumor cells or circulating micrometastases in vivo, macrophages may rely upon the expression of one or more cytotoxic effector mechanisms, some requiring cell-to-cell contact and others dependent on the elaboration of soluble effector molecules such as cytolytic proteases, TNF- $\alpha$, and active oxygen species, i.e., peroxides and nitric oxide (NO) ${ }^{1}(1-5)$. Phagocytosis, i.e., the uptake of particles, by macrophages can be accompanied by the release of specific molecules. The contact between a suitable particle and its receptor on the surface of a macrophage elicits the production of compounds such as reactive oxygen species and NO. The close contact of the particle to be phagocytosed with a specific receptor or binding site seems to be sufficient to trigger response (6). Goodrum et al. (7) have reported recently that ligated complement receptor type 3 (CR3; CD11b/CD18) and IFN- $\gamma$ act synergistically to induce NO production and that CR3 mediates the group B streptococcus-induced signal for NO production in IFN-treated macrophages.

Kupffer cells are the macrophages of the liver and represent the largest population of fixed mononuclear phagocytes in the body (8). Recent reports from our laboratory indicate that NO mediates mitochondrial dysfunction in syngeneic hepatoma cells cocultured with nonactivated Kupffer cells (9), and that ICAM-1/CD18-dependent adhesion to hepatoma cells stimulates Kupffer cells to induce NO synthase and release an excessive amount of NO (10). Consequently, previous studies have suggested that NO released from Kupffer cells modulates biological activities of hepatoma cells, and binding of CD18 and ICAM-1 leads to the NO production by iNOS. Thus, it is of interest to understand the mechanisms by which expression of iNOS is regulated in the cell-to-cell interactions between Kupffer cells and hepatoma cells.

Cells can respond to extracellular stimuli by the de novo synthesis of proteins. A very frequent regulatory event in such responses is the upregulation of mRNA synthesis by transcriptional activator proteins. These sequence-specific DNA binding proteins interact with promoter and enhancer elements of target genes and thereby induce the assembly of a transcription initiation complex. NF-кB is a member of a novel family of transcription factors sharing a common structural motif for DNA binding and dimerization. Xie et al. $(11,12)$ recently cloned a promoter of the murine gene coding for iNOS and demonstrated that the promoter contains NF-кB binding sites. They also reported that activation of $N F-\kappa B / R e l$ is critical in the induction of iNOS by LPS. It is well known that NF- $\kappa$ B is

1. Abbreviations used in this paper: $\mathrm{DCF}$, dichlorofluorescein; DCFHDA, 2'7'-dichlorofluorescin diacetate; DMTU, $N, N^{\prime}$-dimethylthiourea; DPI, diphenylene iodonium; FISH, fluorescence in situ hybridization; NO, nitric oxide; PDTC, pyrrolidine dithiocarbamate; TMB-8, 8-diethyloctylamino trimethoxy benzoate. 
activated by factors such as cytokines, mitogens, LPS, viruses, double-stranded RNA, and agents providing oxidative stress. The activation of NF- $\mathrm{B}$ can be blocked by thiol compounds (13-15). 20-30 mM N-acetyl-L-cysteine $(13,14)$ or $0.5 \mathrm{mM}$ L-cysteine (15) could block NF-кB induction upon treatment of cells with PMA or TNF. The chemical basis for the inhibitory effect of the compounds seemed to lie in an oxygen radical-scavenging effect of the thiol groups. An involvement of reactive oxygen intermediates in the effects of PMA and TNF was further evident from depletion of glutathione levels (14, 16) and release of $\mathrm{H}_{2} \mathrm{O}_{2}$ and $\mathrm{O}_{2}^{-}$when cells are stimulated with PMA or TNF (17-21). More direct evidence that oxygen radicals play a role in the activation of $\mathrm{NF}-\kappa \mathrm{B}$ came from the demonstration that exposure of cells to micromolar amounts of $\mathrm{H}_{2} \mathrm{O}_{2}$ can activate the transcription factor and the $\kappa \mathrm{B}$-dependent induction of a reporter gene under control of the HIV-1 LTR (13). Subsequently, it was shown that induction of NF- $\mathrm{B}$ by many other inducers, such as cycloheximide, double-stranded RNA, bacterial LPS, IL-1, lectin, calcium ionophore (13), and the viral transactivator tax from HTLV-1, was also an important and widely used messenger in the activation of NF- $\mathrm{B}$ (22). Thus, these facts raise a possible scenario that CD18/ ICAM-1-dependent iNOS induction and NO production by Kupffer cells are regulated by oxidative activation of NF-кB. This scenario is tenable inasmuch as that CD18 and ICAM-1 interaction stimulates production of active oxygen species (23).

Although calcium ionophore such as A23187 is also known as an NF-кB-inducing agent, roles for calcium in this activation process have not been fully investigated. It is postulated that calcium mobilization leads to oxidative NF- $\mathrm{KB}$ activation, because calcium ionophore-dependent activation of NF- $\mathrm{BB}$ is inhibitable with antioxidants (24). Interestingly, the oscillatory activity of cytosolic free calcium in adherent neutrophils is mediated through the CD11b/CD18 integrins (25). More recent studies further suggested that ligation of monocyte integrins with antibodies results in a rapid increase in message levels for inflammatory mediator genes including IL-1 $\beta$, TNF- $\alpha$, and IL-8, and that the $5^{\prime}$ regulatory regions of many of the genes induced by integrin ligation contain binding motifs for the NF $\kappa \mathrm{B}$. These findings led us to hypothesize that cell-to-cell adhesive interactions via CD18 and ICAM-1 cause calcium-mediated $\mathrm{NF}-\kappa \mathrm{B}$ activation in Kupffer cells.

Thus, major objectives of this study were: $(a)$ to estimate whether NO is released from rat Kupffer cells in response to coculture with hepatoma cells; $(b)$ to investigate the mechanisms by which Kupffer cells synthesize and release NO in response to hepatoma cells; and (c) to evaluate to what extent calcium mobilization and oxygen radical are involved in the process for NF- $\kappa \mathrm{B}$ activation leading to $\mathrm{NO}$ production in Kupffer cells. These issues were addressed by using fluorographic studies performed under a laser scanning confocal microscope.

\section{Methods}

Cell preparation. Kupffer cells were isolated from male Wistar rats (200-250 g) according to the method described previously $(9,10,26)$. Isolated Kupffer cells were cultured for $48 \mathrm{~h}$ before each experiment at $37^{\circ} \mathrm{C}$ under a humid atmosphere of $5 \% \mathrm{CO}_{2}$. A rat hepatoma cell line, AH70, was used as a target to determine the cytotoxic effect of Kupffer cells $(9,10)$. AH70 cells were seeded at $24 \mathrm{~h}$ before experiments and cultured at $37^{\circ} \mathrm{C}$ under a humidified atmosphere of $5 \%$
$\mathrm{CO}_{2}$. DMEM (Gibco Laboratories, Grand Island, NY) with $10 \%$ FCS (Gibco Laboratories), $100 \mathrm{IU} / \mathrm{ml}$ of penicillin (Gibco Laboratories), and $100 \mu \mathrm{g} / \mathrm{ml}$ of streptomycin (Gibco Laboratories) was used as the medium in this culture system $(9,10)$. When the viability of cultured cells was $>95 \%$ as determined by the trypan blue exclusion test, the cells were used for the experiments $(9,10,26)$. Every precaution was taken in our laboratory to ensure that additives, medium, and plastic materials used in the course of this study were free of endotoxin as measured by Limulus amebocyte lysate test kit (Whittaker Bioproducts, Walkersville, MD) which has a sensitivity of $0.1 \mathrm{ng} / \mathrm{ml}$.

Fluorescence in situ hybridization for iNOS mRNAs. Induction of iNOS mRNA in cultured cells was investigated by the method of fluorescence in situ hybridization $(F I S H)$. Cultured cells in an 8-well Lab Tek tissue culture chamber were washed three times with PBS ( $\mathrm{pH}$ 7.4) and fixed with $4 \%$ paraformaldehyde for $30 \mathrm{~min}$. After being washed three times with PBS, cells were incubated with $0.2 \mathrm{~N} \mathrm{HCl}$ for 15 min at toom temperature. The chamber was rinsed with PBS, and then the cells were incubated with proteinase K $(2 \mu \mathrm{g} / \mathrm{ml}$, Sigma Chemical Co., St. Louis, MO) for $10 \mathrm{~min}$ at $37^{\circ} \mathrm{C}$. After washing, the cells were fixed again with $4 \%$ paraformaldehyde for $5 \mathrm{~min}$. After washing three times with glycine solution $(2 \mathrm{mg} / \mathrm{ml}$ in PBS), the cells were incubated in a prehybridization buffer containing formamide $(50 \mathrm{ml}), 5 \times \mathrm{SSC}(25 \mathrm{ml}), 0.1 \%$ (wt/vol) SDS $(1 \mathrm{ml}), 6 \%(\mathrm{wt} / \mathrm{vol}) \mathrm{dex}-$ tran sulphate $(10 \mathrm{ml})$ in total $100 \mathrm{ml}$ for $30 \mathrm{~min}$ at $42^{\circ} \mathrm{C}$. The cells were then incubated in the same buffer supplemented with cDNA for rat iNOS which was prelabeled with fluorescein-11-dUTP by using a fluorescein gene images labeling and detection system (Amersham, Buckinghamshire, United Kingdom). After overnight incubation at $42^{\circ} \mathrm{C}$, the culture chamber was washed twice with $1 \times$ SSC containing $0.1 \%$ (wt $/ \mathrm{vol}$ ) SDS and then with $0.5 \times$ SSC containing $0.1 \%$ SDS. The coverslipped chamber was settled under an inverted-type fluorescence microscope (Diaphot, TMD-2S; Nikon, Tokyo, Japan). Confocal imaging was performed using an MRC 600 confocal microscope (Bio Rad, Watford, United Kingdom) mounted on the inverted-type fluorescence microscope with a $63 \times$ oil immersion lens. A multipleline argon-ion laser beam $(25 \mathrm{~mW})$ was used for a single fluorescein emission after excitation at $488 \mathrm{~nm}$ with a filter for fluorescein (10). Laser scanning confocal and conventional fluorescence microscopic observations were carried out by an examiner who was blinded to the treatments.

Immunofluorescence studies on iNOS. The distribution of iNOS protein in AH70 cells and Kupffer cells was observed under the same laser scanning confocal imaging system (10). Cultured AH70 cells and rat Kupffer cells in an 8-well Lab Tek tissue culture chamber were washed three times with PBS ( $\mathrm{pH} 7.4$ ) and fixed with 4\% paraformaldehyde for $30 \mathrm{~min}$. After being washed three times with PBS, cells were incubated in PBS containing $0.1 \%$ Triton X 100 for 5 min. The cells were rinsed in PBS and thereafter incubated with PBS containing $1 \%$ BSA and a mouse monoclonal antibody directed against iNOS (N32020; Transduction Laboratories, Lexington, KY; final concentration $5 \mu \mathrm{g} / \mathrm{ml}$ ) for $60 \mathrm{~min}$ at $4^{\circ} \mathrm{C}$. After washing three times with PBS containing 1\% BSA, the cells were incubated with an FITC-conjugated rabbit anti-mouse $\operatorname{IgG}_{2 \mathrm{a}}$ antibody $(20 \mu \mathrm{g} / \mathrm{ml}$; Zymed Laboratories Inc., South San Francisco, CA) dissolved in PBS containing 1\% BSA for $20 \mathrm{~min}$ at room temperature in the dark. Cells were washed again, and a nonfluorescent cover slip was mounted on the chamber slide. Confocal imaging was performed as described above.

Nitrite and nitrate levels in the culture media. Isolated Kupffer cells and AH70 cells were either individually cultured or cocultured in DMEM $\left(1 \times 10^{6}\right.$ cells $\left./ \mathrm{ml}\right)$ for $24 \mathrm{~h}$. The combined level of nitrite and nitrate in the culture medium was determined using a minor modification (27) of the method described by Granger et al. (28) in which all nitrate is reduced to nitrite by Escherichia coli-derived nitrate reductase (Sigma Chemical Co.). $100 \mu l$ of culture medium was incubated for $60 \mathrm{~min}$ at $37^{\circ} \mathrm{C}$ in a $500-\mu \mathrm{l}$ reaction volume containing $0.1 \mathrm{M}$ Hepes buffer ( $\mathrm{pH} 7.4$ ), $0.3 \mathrm{M}$ ammonium formate, and $0.05 \mathrm{U} / \mathrm{ml} E$. coli-derived nitrate reductase. After the incubation period, the reaction solutions were centrifuged and the supernatant was added to 1 
$\mathrm{ml}$ of the Griess reaction. Absorbance at $543 \mathrm{~nm}$ was recorded, and nitrite and nitrate levels were determined from standard plots which were made by using various concentrations of sodium nitrite (Sigma Chemical Co.) and sodium nitrate (Sigma Chemical Co.).

Fluorescence in situ DNA-protein binding assay for detecting $N F-\kappa B$ activation. Cultured cells on an 8-well slide chamber were fixed with $2 \%$ paraformaldehyde at room temperature for $30 \mathrm{~min}$. After washing three times with Hepes buffer $(10 \mathrm{mM}$ Hepes- $\mathrm{NaOH}, 40 \mathrm{mM}$ $\mathrm{NaCl}, 0.1 \mathrm{mM}$ EDTA, pH 7.4), cells were incubated with Hepes buffer containing $0.2 \mathrm{mg} / \mathrm{ml} \mathrm{DNasel} \mathrm{(Sigma} \mathrm{Chemical} \mathrm{Co.)} \mathrm{at} 30^{\circ} \mathrm{C}$ for $30 \mathrm{~min}$. After washing three times, cells were further incubated with Hepes buffer containing $0.25 \%$ bovine serum albumin (Sigma Chemical Co.), $1 \mu \mathrm{g} / \mathrm{ml}$ poly [dl-dC] (Sigma Chemical Co.), $100 \mathrm{ng} / \mathrm{ml}$ poly dC (Sigma Chemical Co.), and $1 \mathrm{ng} / \mathrm{ml}$ FITC-labeled oligodeoxynucleotides including consensus sequence for an NF-кB binding site of iNOS gene (5'-TGG $\boldsymbol{G G A} \boldsymbol{C T C} \boldsymbol{T C C}$ CTT TGG GAA CAG TTA TGC AAA ATA GCT CTG-3' -FITC) $(11,12)$ at $30^{\circ} \mathrm{C}$ for $60 \mathrm{~min}$ in the dark. As negative controls, either $1 \mathrm{ng} / \mathrm{ml} 5^{\prime}$-ACG AGC TAT TTT GCA TAA CTG TTC CCA AAG GGA GAG TCC CCA-3' FITC or $1 \mathrm{ng} / \mathrm{ml}$ 5'-TGG $\boldsymbol{G A} \boldsymbol{G} \boldsymbol{A} \boldsymbol{G T} \boldsymbol{C C C}$ CTT TGG GAA CAG TTA TGC AAA ATA GCT CTG-3' -FITC was used as the oligodeoxynucleotides. Cells were washed again, and a nonfluorescent cover slip was mounted on the chamber slide. Confocal imaging was performed as described above. The number of fluorescence-positive Kupffer cells was calculated in the 10 randomly selected fields of the conventional fluorescence microscope (magnification of 1,000).

Intracellular calcium mobilization. To monitor the intracellular level and distribution of $\mathrm{Ca}^{2+}$ in Kupffer cells, Kupffer cells were preloaded with $5 \mu \mathrm{M}$ fluo-3 (Dojin, Kumamoto, Japan), a calcium-sensitive fluorescence dye, for $60 \mathrm{~min}(29,30)$. Fluorographic alterations were observed under the experimental conditions described below. Confocal imaging was performed using the same laser scanning confocal microscopic system. A multiple-line argon-ion laser beam (25 $\mathrm{mW}$ ) was used for single fluorescein emission after excitation at 488 $\mathrm{nm}$ with a filter for fluorescein. This procedure allowed a sharp visu- alization of weak labelings even with the highest magnification. Photomicrographic images of the cocultures were also recorded with a transillumination light source for the microscope. From these images, the area of each Kupffer cell was determined on a computer monitor. Temporal alterations of fluorescence intensity in each Kupffer cell was automatically calculated with the digital imaging processor and expressed as gray level units (0-255 counts) per unit area (pixel) by a computer-assisted image analyzing system (Macintosh, Apple Computers, Cupertino, CA).

To further quantify the fluo-3-associated fluorescence intensity, a fluorescence laser scanning system equipped with a computer-assisted image analyzer (FluorImager 575; Molecular Dynamics, Sunnyvale, CA) was used. Kupffer cells cultured on 96-well multititer plate $\left(1 \times 10^{5}\right.$ per well) were loaded with $5 \mu \mathrm{M}$ fluo-3 for $60 \mathrm{~min}$. After washing several times with DMEM, the plate was settled in the fluorescence scanner. The laser scanning was performed, and the fluoroimage was displayed on the computer monitor. Fluorescence intensity in each well was calculated by using an analysis software (ImageQuant; Molecular Dynamics). The fluo-3 fluorescence intensity was expressed according to the following formula:

fluo-3 fluorescence \% intensity $=\frac{I t-I c}{I b-I c} \times 100$

where It is intensity at each time period, Ib is intensity before treatment, and Ic is intensity 5 min after addition of 8-diethyloctylamino trimethoxy benzoate (TMB-8, $100 \mu \mathrm{M}$, Sigma Chemical Co.), an intracellular $\mathrm{Ca}^{2+}$ scavenger, to the culture medium.

Intracellular oxidation. To investigate temporal alterations of oxidative stress in individual Kupffer cells, 2'7'-dichlorofluorescin diacetate (DCFH-DA; Eastman Kodak Co., Rochester, NY) was used according to the method of Cathcart et al. (31) with some modifications. Cultured rat Kupffer cells were incubated with DMEM ( $\mathrm{pH} 7.4$ ) containing $1 \mu \mathrm{M}$ DCFH-DA for $20 \mathrm{~min}$ at $37^{\circ} \mathrm{C}$ in the dark. The cells were washed three times with DMEM to remove the extracellular
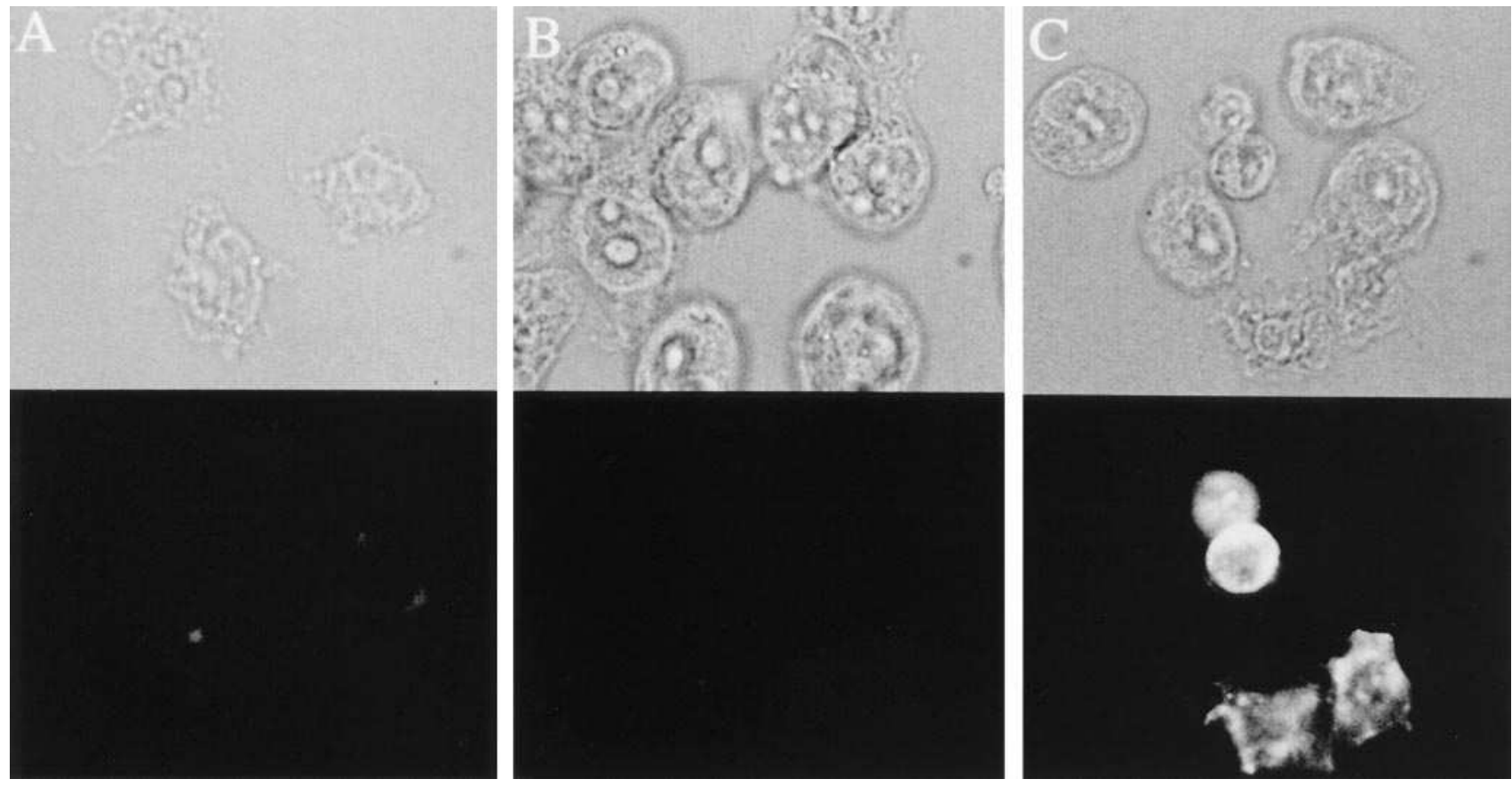

Figure 1. Laser scanning confocal microscopic observations for the expression of iNOS mRNA on AH70 cells and rat Kupffer cells. Kupffer cells $(A)$ and AH70 cells $(B)$ were subjected to mRNA FISH observations using fluorescence-labeled antisense olgonucleotides against iNOS mRNA. Fluorographs were obtained through the laser scanning confocal microscope $(\times 1,260$ original magnification $)$. The fluorescence was found to exist in the cytosol of Kupffer cells which attached to AH70 cells $4 \mathrm{~h}$ after coculture $(C)$. In the transilluminated images shown in the upper portion. 
DCFH-DA. Cells, adequate for the assay, were selected in the microscopic frame, and the green fluorescence was visualized by using the same confocal laser scanning fluorescence analyzing system described above. The alterations of dichlorofluorescein (DCF), which is the oxidized form of DCFH, -associated fluorescence were quantified and expressed according to the same procedure used for quantification of fluo-3 fluorescence (without use of TMB-8).

Experimental protocol. Cultured AH70 cells were collected with a cell scraper, and AH70 cell-containing culture medium was added to the cultured Kupffer cells to give a final AH70/Kupffer ratio of 1:10. The coculture of AH70 cells and Kupffer cells was carried out for an additional $8 \mathrm{~h}$. In the control, the culture medium of Kupffer cells was exchanged, and Kupffer cells were cultured for an additional $8 \mathrm{~h}$ without coculture with AH70 cells. In some experiments, effects of sense (5'-GTGCTAATGCGGAAGGTCATG, $20 \mu \mathrm{M}$ ) and antisense (5'CATGACCTTCCGCATTAGCAC, $20 \mu \mathrm{M}$ ) oligonucleotides against iNOS mRNA were examined by adding these oligonucleotides at the start of coculture. To further assess the role of NF-кB, $100 \mu \mathrm{M}$ pyrrolidine dithiocarbamate (PDTC; Sigma Chemical Co.), an inhibitor of oxidative NF-кB activation (32), was added to the culture medium. To elucidate involvements of active oxidants in the activation process of NF-кB, either N,N'-dimethylthiourea (DMTU, $10 \mathrm{mM}$; Janssen Chimica, B-2440 Geer, Belgium), a small, permeable, and relatively nontoxic scavenger of hydrogen peroxide and the hydroxyl radical $(33,34), 10 \mu \mathrm{M}$ diphenylene iodonium (DPI; Sigma Chemical Co.) (35), an NADPH oxidase inhibitor, or $5 \mu \mathrm{M}$ quinacrine (Sigma Chemical Co.) (35), a phospholipase $\mathrm{A}_{2}$ inhibitor, was added to the culture medium. To examine possible involvement of calcium mobilization, $100 \mu \mathrm{M}$ TMB-8 was added to the coculture system. To examine involvements of adhesion molecules such as CD18 and ICAM-1, either a mouse monoclonal antibody $\left(\mathrm{mAb} \mathrm{IgG}_{1}\right)$ directed against rat ICAM-1 (1A29; Seikagaku Co., Tokyo, Japan) or CD18 (WT-3; Seikagaku Co.) was administered to the culture medium to give a final concentration of $60 \mu \mathrm{g} / \mathrm{ml}(10)$.
In another series of experiments, a calcium ionophore, $10 \mu \mathrm{M}$ A23187 (Sigma Chemical Co.), was added to the culture medium of Kupffer cells, and the same investigations were performed.

Statistical analysis. The data obtained in this study are expressed as the means $\pm \mathrm{SE}$ of six experiments, which were individually performed using Kupffer cells isolated from different rats. The data were analyzed using a standard statistical procedure, i.e., ANOVA with Scheffe's post-hoc test. Statistical significance was set at $P<0.05$.

\section{Results}

Fig. 1 demonstrates the expression of iNOS mRNA which was detected by the mRNA FISH method. The iNOS mRNAassociated fluorescence in the cytosol of Kupffer cells which were cocultured with AH70 cells for $4 \mathrm{~h}$ but not in AH70 cells themselves was clearly visualized under the laser scanning confocal microscope (Fig. $1 C$ ). The mRNA was not detected in individually cultured Kupffer cells (Fig. $1 B$ ) or AH70 cells (Fig. $1 A$ ).

Fig. 2 represents the laser scanning confocal microscopic observations on expressions of iNOS in coculture system of AH70 cells and rat Kupffer cells. Anti-iNOS mAb-associated fluorescence was not found on individually cultured AH70 cells (Fig. $2 \mathrm{~A}$ ) or Kupffer cells (Fig. $2 \mathrm{~B}$ ). After $8 \mathrm{~h}$ of coculture, a marked increase in the fluorescence of anti-iNOS mAb was observed in the cytosol of Kupffer cells, which closely adhered to AH70 cells, but not in AH70 cells (Fig. 2 C).

Table I summarizes the nitrite and nitrate levels in the culture medium $8 \mathrm{~h}$ after each treatment. The coculture of Kupffer cells with AH70 cells significantly increased the nitrite and nitrate levels in the culture medium (11-fold increase).
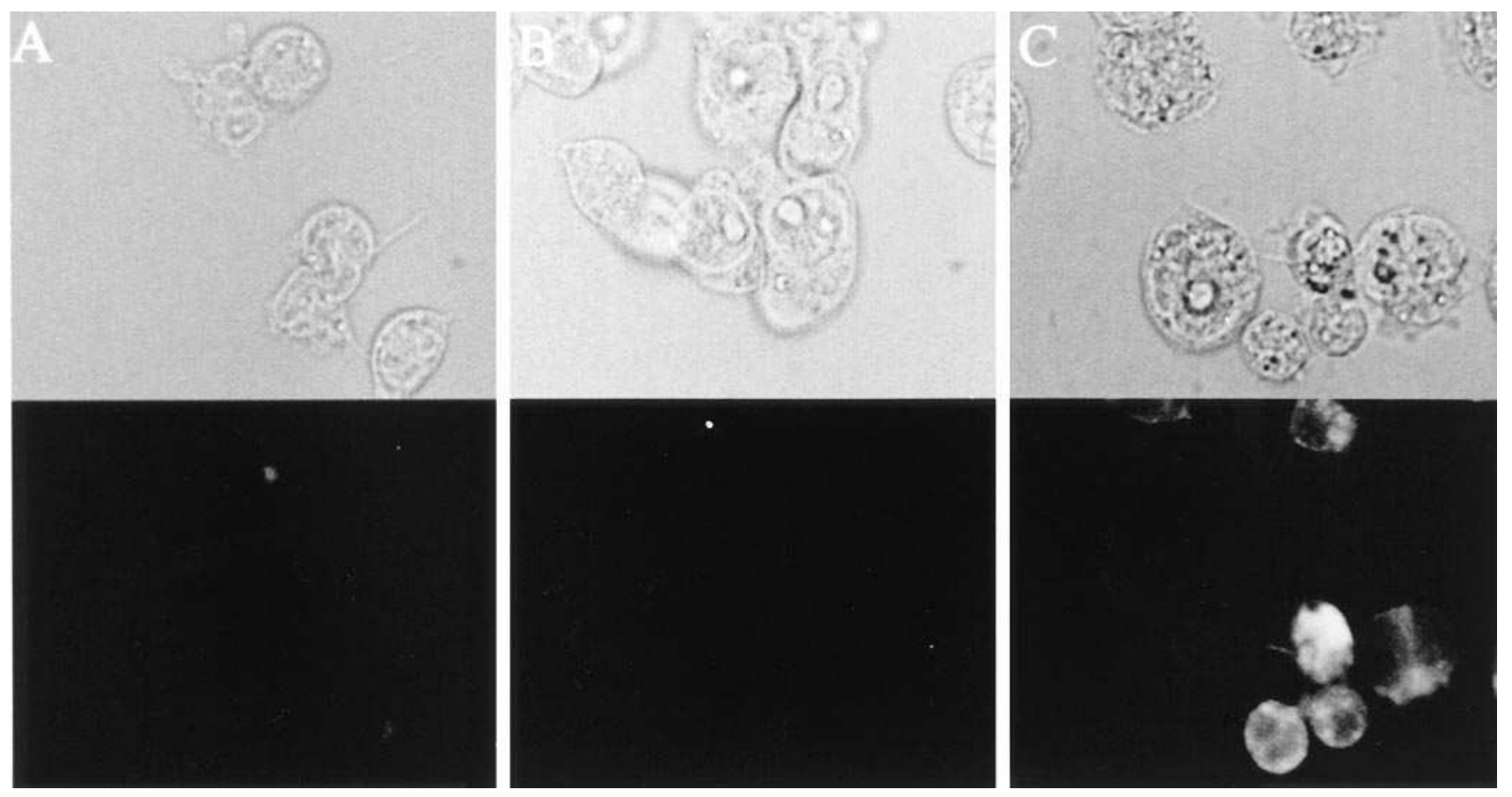

Figure 2. Laser scanning confocal microscopic observations for the expression of iNOS on AH70 cells and rat Kupffer cells. Kupffer cells $(A)$ and $\mathrm{AH} 70$ cells $(B)$ were subjected to immunofluorescence observations using anti-iNOS monoclonal antibody. Fluorographs were obtained through the laser scanning confocal microscope $(\times 1,260$ original magnification). The iNOS-associated fluorescence was found to exist in cytosol of Kupffer cells which closely adhered to AH70 cells $8 \mathrm{~h}$ after the coculture $(C)$. In the transilluminated images shown in the upper portion. 
Table I. Nitrite and Nitrate Levels in Culture Media

\begin{tabular}{|c|c|}
\hline Treatment & Nitrite and nitrate \\
\hline & $\mu M$ \\
\hline AH70 cells & $18.6 \pm 2.2$ \\
\hline Kupffer cells & $24.3 \pm 5.4$ \\
\hline AH70 cells cocultured with Kupffer cells & $265.3 \pm 20.3 * \ddagger$ \\
\hline+ Antisense iNOS & $88.4 \pm 7.5^{* \ddagger \S}$ \\
\hline+ Sense iNOS & $289.3 \pm 24.0 * \ddagger$ \\
\hline+ mAb CD18 & $145.6 \pm 20.9 * \div \S$ \\
\hline+ mAb ICAM-1 & $189.6 \pm 33.3 * \div \S$ \\
\hline+ TMB-8 & $158.0 \pm 20.7 * \$ \S$ \\
\hline$+\mathrm{DPI}$ & $115.6 \pm 11.4 * \$ \S$ \\
\hline + Quinacrine & $177.6 \pm 15.9 * \div \S$ \\
\hline+ PDTC & $108.0 \pm 14.6^{* \$ \S}$ \\
\hline+ DMTU & $110.3 \pm 21.0 * \div \S$ \\
\hline
\end{tabular}

The data were obtained $8 \mathrm{~h}$ after each treatment and are expressed as the means $\pm \mathrm{SE}$ of six experiments. ${ }^{*} P<0.05$ as compared with AH70 cells alone $\left(1 \times 10^{5}\right.$ cells $\left./ \mathrm{ml}\right) ;{ }^{\ddagger} P<0.05$ as compared with Kupffer cells alone $\left(1 \times 10^{6}\right.$ cells $\left./ \mathrm{ml}\right) ;{ }^{\S} P<0.05$ as compared with AH70 cells $\left(1 \times 10^{5}\right.$ cells $/ \mathrm{ml})$ cocultured with Kupffer cells $\left(1 \times 10^{6}\right.$ cells $\left./ \mathrm{ml}\right)$

The increase in the nitrite and nitrate levels after the coculture was effectively attenuated by the addition of antisense oligonucleotides against iNOS mRNA (70\% inhibition) but not by sense oligonucleotides. Addition of either DMTU, PDTC, TMB-8, DPI, quinacrine, mAb directed against CD18, or ICAM-1 significantly attenuated the increased level of nitrite and nitrate observed in the culture medium of Kupffer cells cocultured with AH70 cells.

Fig. 3 shows the distribution of activated NF-кB in Kupffer
Table II. Number of the DNA-Protein Binding-associated Fluorescence Positive Kupffer Cells 1 h after Each Treatment

\begin{tabular}{lc}
\hline \multicolumn{1}{c}{ Treatment } & Number of Kupffer cells \\
\hline & $\%$ \\
Kupffer cells & $2.5 \pm 0.5$ \\
Kupffer cells cocultured with AH70 cells & $45.6 \pm 3.5^{*}$ \\
+ Antisense iNOS & $44.1 \pm 5.6^{*}$ \\
+ Sense iNOS & $51.3 \pm 7.7^{*}$ \\
+ mAb CD18 & $12.6 \pm 2.7^{* \ddagger}$ \\
+ mAb ICAM-1 & $25.6 \pm 4.1^{* \ddagger}$ \\
+ TMB-8 & $11.5 \pm 1.9^{* \ddagger}$ \\
+ DPI & $15.6 \pm 3.0^{* \neq}$ \\
+ Quinacrine & $19.9 \pm 2.8^{* \neq}$ \\
+ PDTC & $8.9 \pm 1.7^{* \ddagger}$ \\
+ DMTU & $11.5 \pm 2.0^{* \ddagger}$ \\
\end{tabular}

Data were obtained $1 \mathrm{~h}$ after each treatment and are expressed as the means \pm SE of six experiments. ${ }^{*} P<0.05$ as compared with Kupffer cells alone; ${ }^{\ddagger} P<0.05$ as compared with Kupffer cells cocultured with AH70 cells.

cells and $\mathrm{AH} 70$ cells, which was visualized by the fluorescence in situ DNA-protein binding assay. The NF- $\mathrm{B}$ reactive oligonucleotides-associated fluorescence was not found on individually cultured AH70 cells of Kupffer cells (Fig. 3 A). Within 30 min after the coculture with AH70 cells, the fluorescence was detected in cytosol and nucleus of Kupffer cells (Fig. 3 B). The fluorescence was further accumulated in nuclei of Kupffer cells $1 \mathrm{~h}$ after the coculture with AH70 cells (Fig. $3 \mathrm{C}$ ). When the control oligodeoxynucleotides were used, no significant fluo-
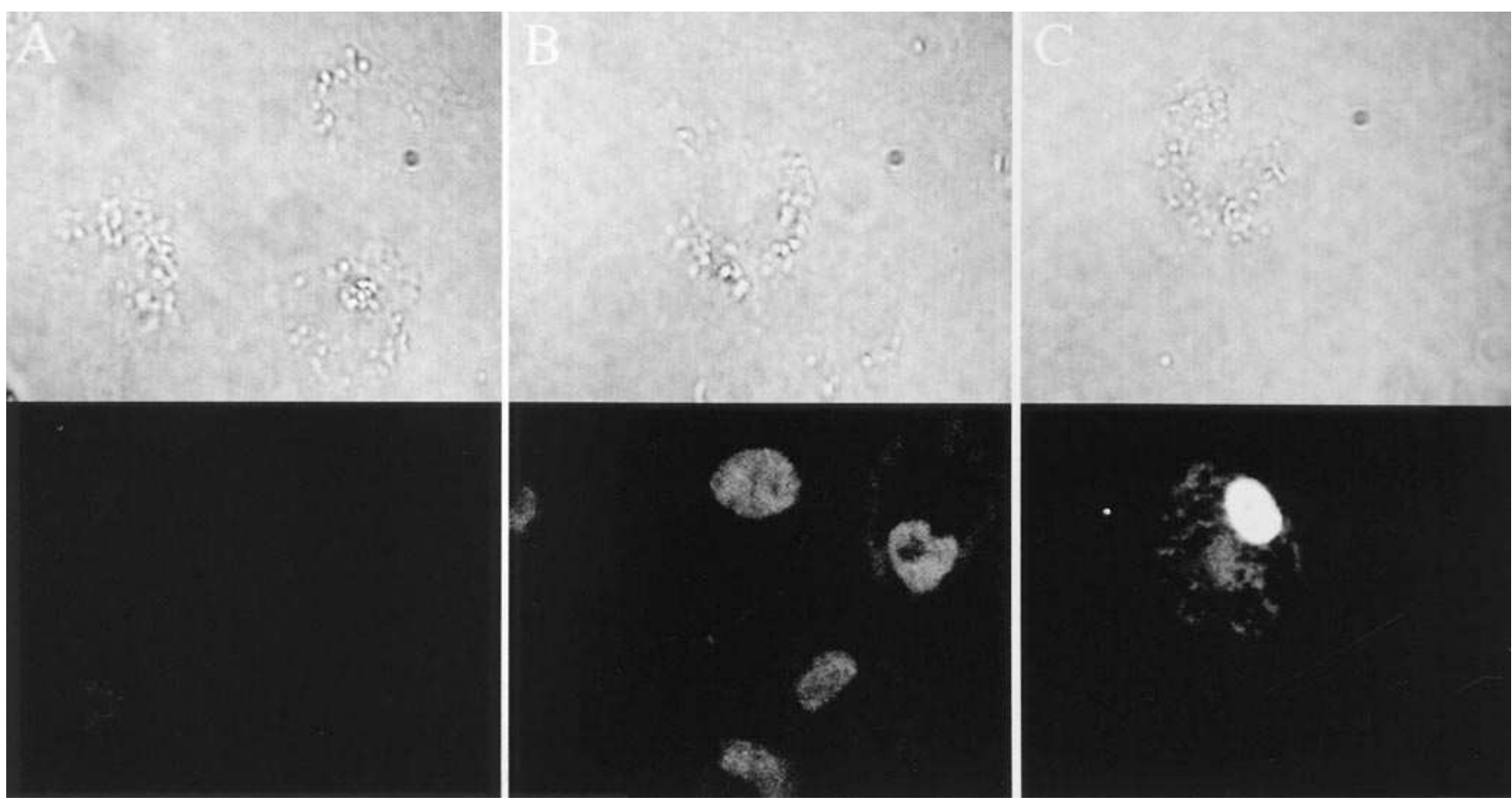

Figure 3. Distribution of activated NF-кB in Kupffer cells and AH70 cells visualized by the fluorescence in situ DNA-protein binding assay. The $\mathrm{NF}-\kappa \mathrm{B}$ reactive oligonucleotides-associated fluorescence was not found on Kupffer cells cultured alone $(A)$. Within 30 min, the fluorescence was detected in cytosol and nucleus of Kupffer cells cocultured with AH70 cells $(B)$. The fluorescence was further accumulated in nuclei of Kupffer cells $1 \mathrm{~h}$ after coculture with AH70 cells $(C)$. 

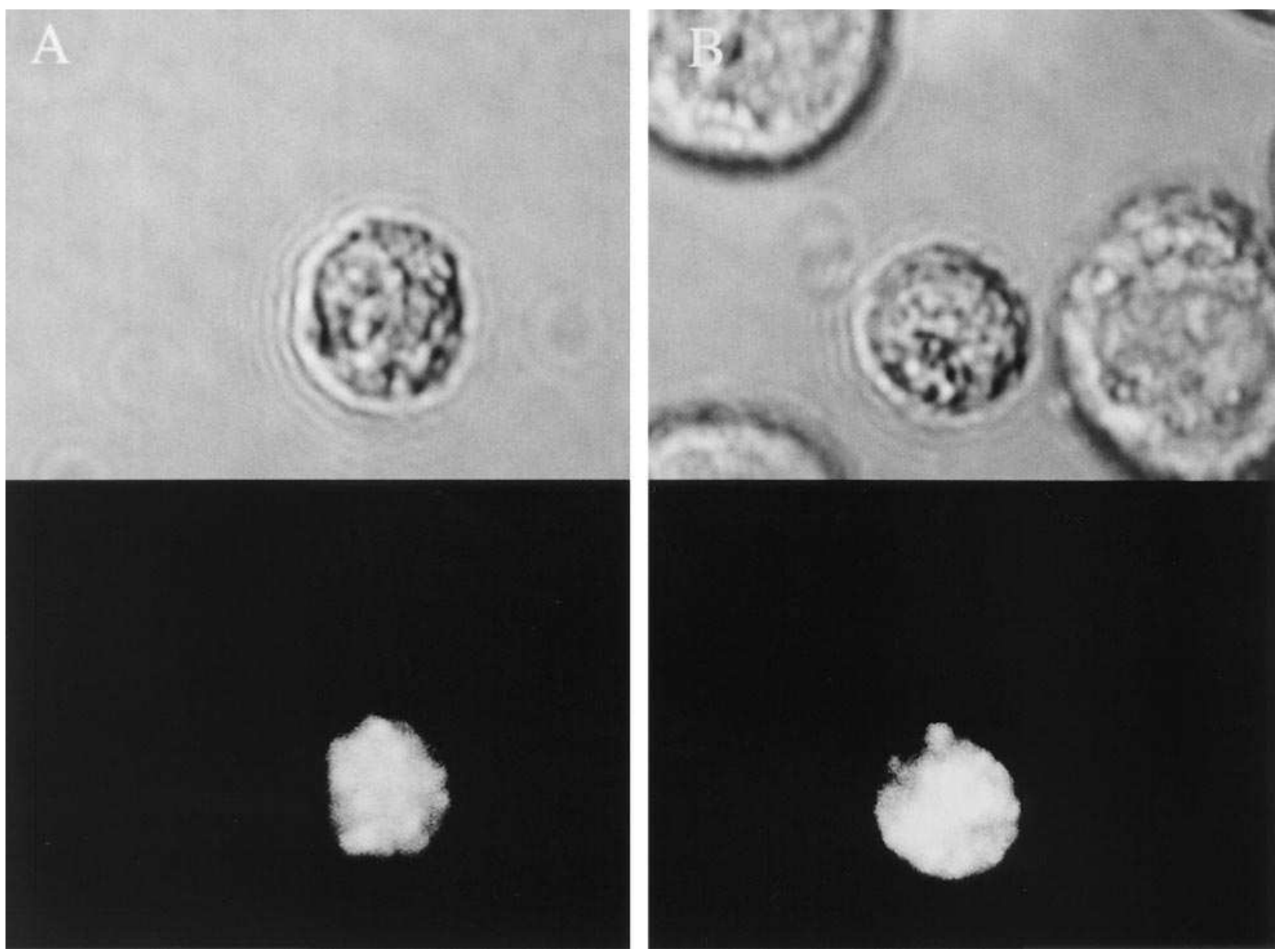

Figure 4. DCF fluorescence in Kupffer cells. DCF fluorescence was visualized through the laser scanning confocal microscope. The fluoresence increased in Kupffer cells adhered to AH70 cells $(B)$ as compared with that before addition of AH70 cells to the culture medium $(A)$. $\times 2,520$ original magnification.

rescence was detected in Kupffer cells even $1 \mathrm{~h}$ after the coculture (fluorograph was not shown).

Table II summarizes the number of Kupffer cells with the DNA-protein binding-associated fluorescence $1 \mathrm{~h}$ after each treatment. Without coculture with AH70 cells, the number was $<3 \%$, whereas the activated NF- $\mathrm{B}$ was observed in $45.6 \pm$ $3.5 \%$ of Kupffer cells subjected to coculture with AH70 cells. The increase in the number of Kupffer cells with activated NF- $\kappa \mathrm{B}$ was significantly attenuated by addition of either DMTU (80\% inhibition), PDTC (80\% inhibition), TMB-8 ( $75 \%$ inhibition), DPI (66\% inhibition), quinacrine (56\% inhibition), $\mathrm{mAb}$ directed against $\mathrm{CD} 18$ (72\% inhibition), or ICAM-1 (44\% inhibition). Neither antisense nor sense oligodeoxynucleotides against iNOS and mRNA attenuated the NF- $\kappa$ B activation in Kupffer cells.

Fig. 4 shows DCF fluorescence in Kupffer cells before and after the coculture with AH70 cells. DCF diffusely labeled the cytosol of cultured Kupffer cells preloaded with DCFH-DA (Fig. $4 A$ ). DCF fluorescence in Kupffer cells which adhered to AH70 cells increased within 10 min after the coculture (Fig. 4 B).

Fig. 5 represents DCF and Fluo-3 fluorescences in Kupffer cells, which were cultured on 96-well titer plates, visualized by the laser scanning fluorescence imager. Each treatment was in- dicated as shown in left side of the figure. Thus, these fluorescences in fluorescence probe-preloaded Kupffer cells were clearly visualized and were successfully measured by the fluorescence imaging system. Fig. 6 compares time course changes in DCF fluorescence of Kupffer cells $\left(1 \times 10^{5}\right.$ per well $)$ measured by the fluorescence measuring system. DCF fluorescence in Kupffer cells alone did not alter during the entire course of the observation period. Within $10 \mathrm{~min}$ after the coculture with AH70 cells, the DCF fluorescence in Kupffer cells increased to $155 \%$ of the baseline value and further elevated to $182 \% 30 \mathrm{~min}$ after the coculture. The fluorescence intensity gradually decreased up to $60 \mathrm{~min}$ after the coculture, however, the level of fluorescence intensity was still higher than that of Kupffer cells alone $(P<0.05)$.

Fig. 7 shows the fluo- 3 fluorescence in Kupffer cells before and after coculture with AH70 cells. The fluo-3 fluorescence in Kupffer cells which adhered to AH70 cells increased within 10 min after coculture (Fig. 7 B).

Fig. 8 compares time course changes in fluo-3 fluorescence of Kupffer cells $\left(1 \times 10^{5}\right.$ per well $)$ measured by the fluorescence measuring system. The fluo-3 fluorescence in Kupffer cells alone did not alter during the entire course of the observation period. Within 10 min after the coculture with AH70 cells, the fluo-3 fluorescence in Kupffer cells increased to a 


\section{DCF Fluorescence}

\section{Fluo-3 Fluorescence}

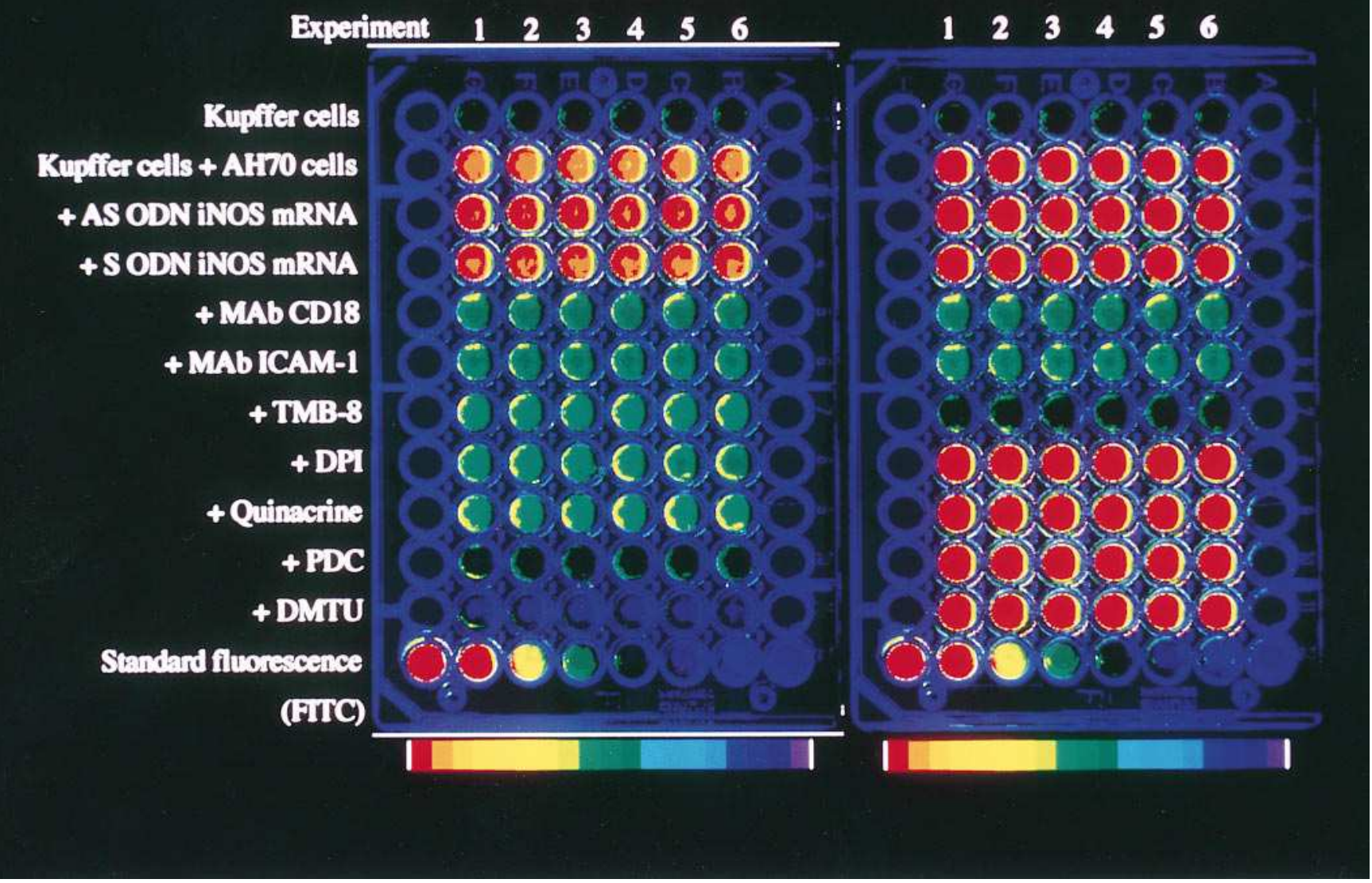

Figure 5. Representative images of DCF and fluo-3 fluorescences visualized by laser scannning fluorescence imager. Kupffer cells were cultured on 96-well titer plates, and loaded with DCFH-DA and fluo-3. Before and after each treatment, fluorographs of DCF and fluo-3 were visualized by the laser scanning fluorescence imager. This photograph shows a representative image of these fluorescences. The bars represent fluorescence intensities as pseudo colors (red $>$ black).

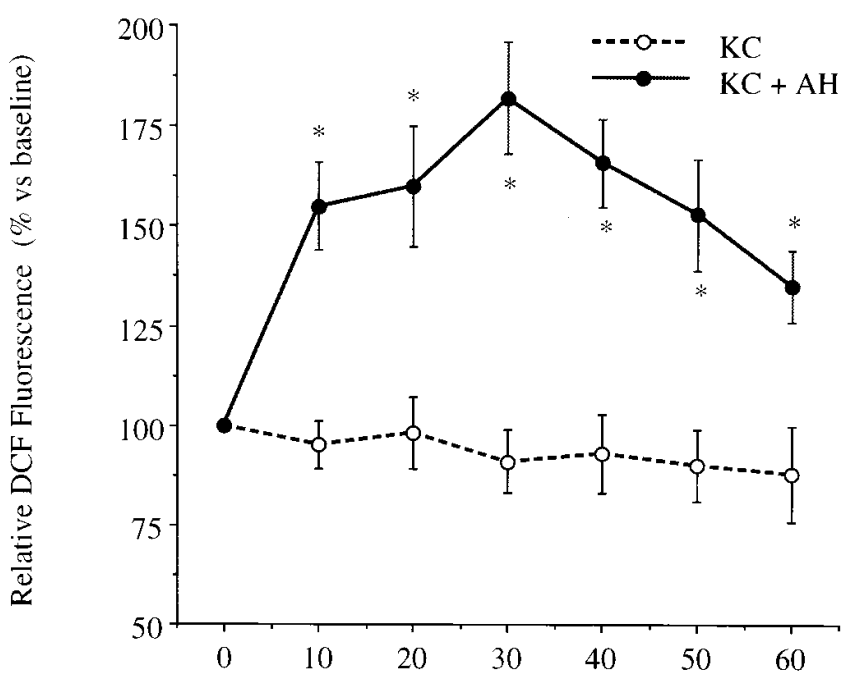

Time $(\min )$

Figure 6. Time course change of DCF fluorescence intensity in Kupffer cells. The relative DCF fluorescence intensity was measured 2-fold higher level than that in Kupffer cells alone, and further elevated to a 2.5 -fold level $30 \mathrm{~min}$ after the coculture. The fluorescence intensity gradually decreased up to 60 min after the coculture, however, the level of fluorescence intensity was still higher than that of Kupffer cells alone $(P<0.05)$.

Table III summarizes effects of agents used in the DCF and fluo-3 studies. Addition of mAbs CD18 and ICAM-1 to the culture medium diminished the increased level of DCF and fluo-3 fluorescence intensities in Kupffer cells cocultured with AH70 cells. TMB-8 also prevented the increases in both fluorescences. DMTU, PDTC, DPI, and quinacrine showed a significant inhibitory effect of DCF activation but not on the increase in fluo-3 fluorescence observed in Kupffer cells cocultured with AH70 cells. Neither antisense nor sense oligodeoxynucleotides against iNOS mRNA attenuated the DCF activation in Kupffer cells.

and calculated by the computer-assisted fluorescence image analyzer as described in Methods. $K C$, Kupffer cells; $A H$, AH70 cells. $* P<$ 0.05 as compared with Kupffer cells alone. 

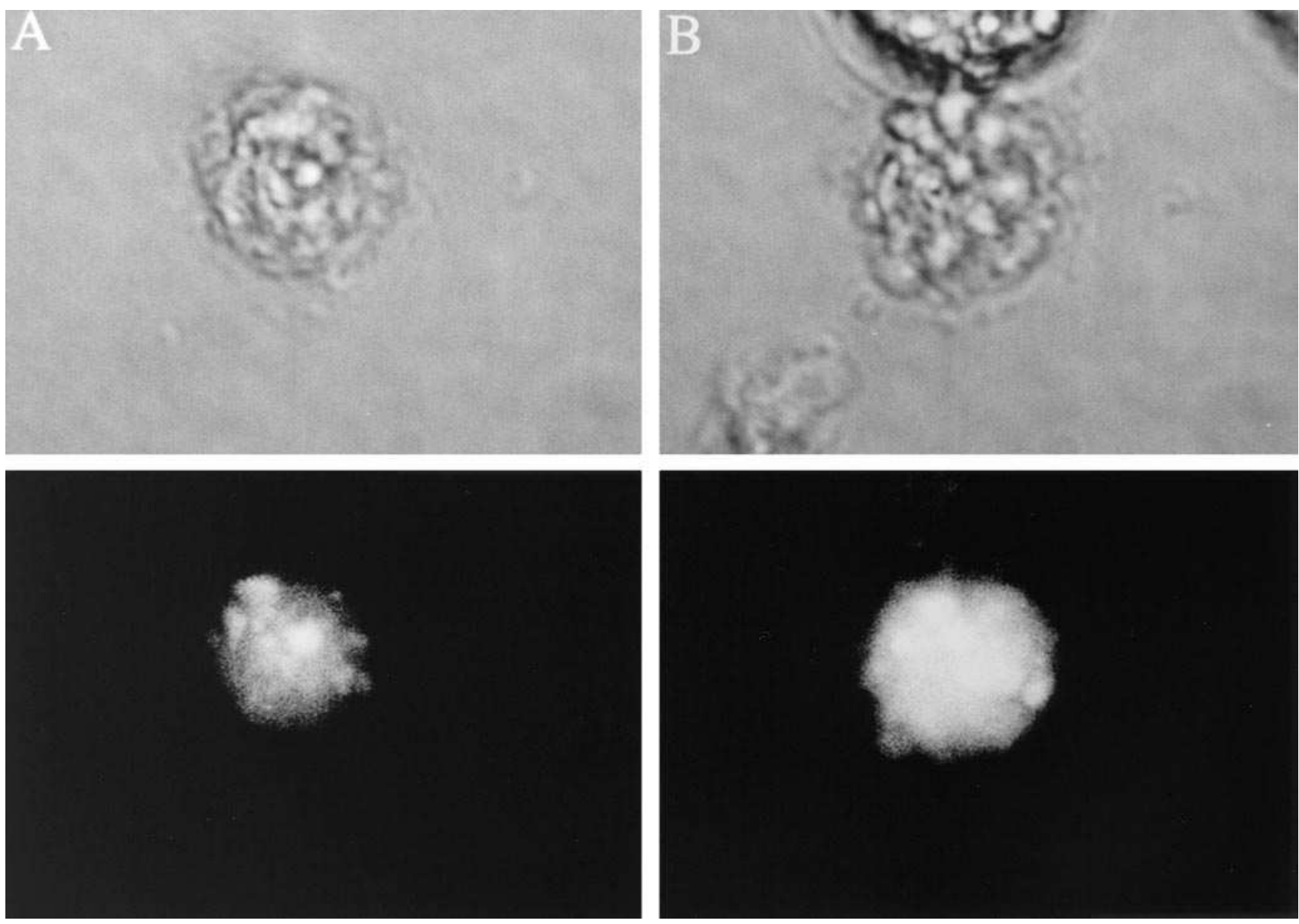

Figure 7. Fluo-3 fluorescence in Kupffer cells. Fluo-3 fluorescence was visualized through the laser scanning confocal microscope. The fluorescence increased in Kupffer cells adhered to AH70 cells $(B)$ as compared with that before addition of AH70 cells to the culture medium $(A)$. $\times 2,520$ original magnification.

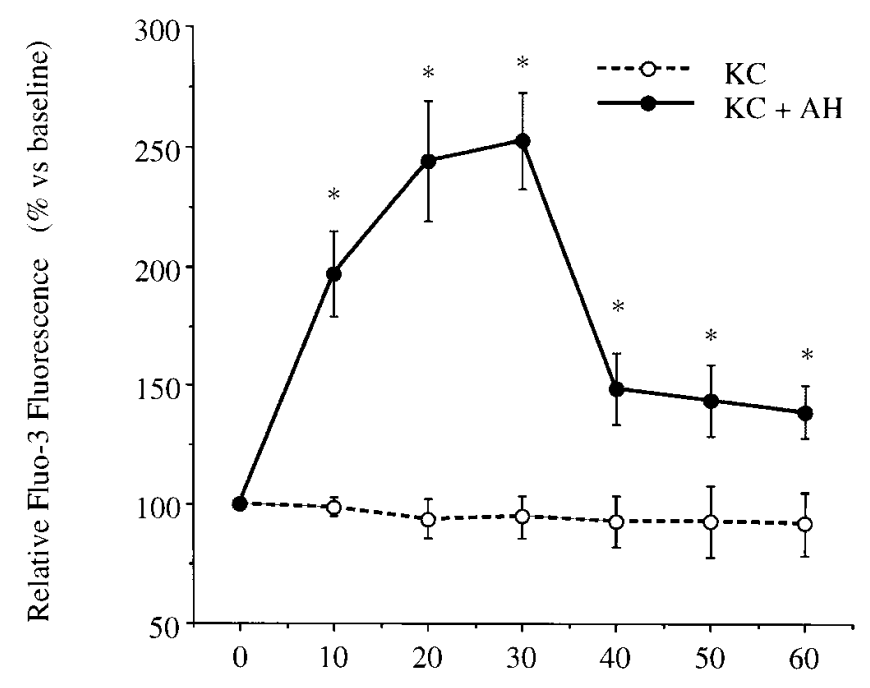

Time (min)

Figure 8. Time course change of fluo-3 fluorescence intensity in Kupffer cells. The relative fluo-3 fluorescence intensity was measured and calculated by the computer-assisted fluorescence image analyzer as described in Methods. $K C$, Kupffer cells; $A H, \mathrm{AH} 70$ cells. ${ }^{*} P<$ 0.05 as compared with Kupffer cells alone.
Table IV summarizes effects of calcium ionophore A23187 on the number of DNA-protein binding-positive Kupffer cells, fluo-3 and DCF fluorescences, and NO production of Kupffer cells. Marked increases in DCF (1.7-fold) and fluo-3 (3.3-fold) fluorescences in Kupffer cells were observed within $10 \mathrm{~min}$ after the addition of A23187. Incubation with A23187 for 60 min also increased the number of DNA-protein binding-positive Kupffer cells by $\sim 60 \%$. The nitrite and nitrate level in the culture medium of Kupffer cells also increased $8 \mathrm{~h}$ after incubation with A23187 (4.5-fold).

\section{Discussion}

This study provided evidence to support the hypothesis that nonactivated Kupffer cells isolated from rat liver synthesize and release NO in response to adhesive interactions with syngeneic hepatoma cells. The present results showing the effects of antisense oligodeoxynucleotides against iNOS mRNA suggest that coculture with AH70 cells actually upregulates NO production at the level of mRNA transcription rather than the level of iNOS protein synthesis. Supportingly, the present FISH and immunofluorescence studies revealed that Kupffer cells adhered to AH70 cells actually express iNOS mRNA as well as iNOS protein in the cytosol. Although the biological effects of macrophage-derived cytotoxic effectors are relatively 
Table III. Effects of Agents on the DCF and Fluo-3

Fluorescences in Kupffer Cells

\begin{tabular}{llc}
\hline \multicolumn{1}{c}{ Treatment } & \multicolumn{1}{c}{ DCF } & \multicolumn{1}{c}{ Fluo-3 } \\
\hline & $\%$ vs. baseline & $\%$ vs. baseline \\
Kupffer cells & $102.2 \pm 9.6$ & $105.6 \pm 11.0$ \\
Kupffer cells cocultured & & \\
$\quad$ with AH70 cells & $198.6 \pm 18.6^{*}$ & $278.6 \pm 24.4^{*}$ \\
+ Antisense iNOS & $198.2 \pm 18.7^{*}$ & $297.6 \pm 16.9^{*}$ \\
+ Sense iNOS & $195.0 \pm 25.0^{*}$ & $309.1 \pm 18.8^{*}$ \\
+ mAb CD18 & $144.4 \pm 10.3^{\ddagger}$ & $162.5 \pm 25.9^{\ddagger}$ \\
+ mAb ICAM-1 & $150.4 \pm 11.3^{* \ddagger}$ & $193.5 \pm 14.9^{* \ddagger}$ \\
+ TMB-8 & $121.8 \pm 4.6^{\ddagger}$ & $111.4 \pm 5.9^{\ddagger}$ \\
+ DPI & $119.6 \pm 5.0^{\ddagger}$ & $248.8 \pm 30.0^{*}$ \\
+ Quinacrine & $126.5 \pm 9.8^{\ddagger}$ & $277.0 \pm 25.3^{*}$ \\
+ PDTC & $122.0 \pm 8.9^{\ddagger}$ & $255.9 \pm 20.9^{*}$ \\
+ DMTU & $136.5 \pm 11.1^{\ddagger}$ & $288.6 \pm 15.9^{*}$ \\
& &
\end{tabular}

Data represent the peak value in the time course change within 60 min after each treatment and are expressed as the means \pm SE of six experiments. ${ }^{*} P<0.05$ as compared with Kupffer cells alone; ${ }^{\sharp} P<0.05$ as compared with Kupffer cells cocultured with AH70 cells.

well known, the present knowledge on the detailed mechanisms by which these cells cause tumor cell death remains incomplete. Previous studies from our laboratory have demonstrated that L-NMMA, an NO synthesis inhibitor, attenuates the mitochondrial dysfunction in hepatoma cells $(9,10)$ as well as hepatocytes (26) induced by rat Kupffer cells. The results of the previous studies also showed that dexamethasone or aminoguanidine, which inhibits iNOS activity but not cNOS activity $(36,37)$, diminishes the Kupffer cell-induced mitochondrial dysfunction in cocultured hepatoma cells (10). Thus, it has been postulated that excessive NO production by iNOS leads to the hepatoma cell injury observed after the coculture with nonactivated Kupffer cells. We have also reported that nonac-
Table IV. Effects of Calcium Ionophore A23187 on the DCF and Fluo-3 Fluorescences in Kupffer Cells, the Number of DNA-Protein Binding Assay-positive Kupffer Cells, and Nitrite and Nitrate Level in the Culture Medium of Kupfer Cells

\begin{tabular}{lllcc}
\hline \multicolumn{1}{c}{ Treatment } & \multicolumn{1}{c}{$\begin{array}{c}\text { Fluo-3 } \\
\text { fluorescence* }\end{array}$} & $\begin{array}{c}\text { DCF } \\
\text { fluorescence* }\end{array}$ & $\begin{array}{c}\text { DNA-protein } \\
\text { binding positive } \\
\text { Kupffer cells }^{\ddagger}\end{array}$ & $\begin{array}{c}\text { Nitrite and } \\
\text { nitrate level }\end{array}$ \\
\hline & $\%$ vs. baseline & $\%$ vs. baseline & $\%$ & $\mu M$ \\
Kupffer cells & $106.7 \pm 6.2$ & $104.9 \pm 4.9$ & $3.3 \pm 0.8$ & $22.2 \pm 4.5$ \\
+ A23187 & $329.5 \pm 41.6$ & $170.9 \pm 117.7 \|$ & $59.5 \pm 8.9 \|$ & $99.6 \pm 8.3^{\|}$ \\
\hline
\end{tabular}

*Data represent the peak value in the time course change within 10 min after each treatment and are expressed as the means \pm SE of six experiments. ${ }^{*}$ Data represent the number of positive Kupffer cells 60 min after each treatment and are expressed as the means $\pm \mathrm{SE}$ of six experiments. ${ }^{\S}$ Data represent the levels in the culture medium $8 \mathrm{~h}$ after each treatment and are expressed as the means \pm SE of six experiments. $\| P<0.05$ as compared with Kupffer cells.

tivated Kupffer cells recognize and adhere to hepatoma cells via CD18/ICAM-1-dependent mechanisms and release NO (9, $10,38)$. In addition, treatment with either CD18 or ICAM-1 monoclonal antibody inhibits NO production and attenuates the Kupffer cell-mediated hepatoma cell injury (10), suggesting the involvement of CD18/ICAM-1 in the signal transduction of Kupffer cells. In this study, incubation with $\mathrm{mAb}$ directed against either CD18 or ICAM-1 significantly attenuated the increase in NO synthesis of Kupffer cells interacted with AH70 cells. Taken together with the previous reports, this study strongly suggests that nonactivated Kupffer cells adhere to hepatoma cells via CD18 and ICAM-1, and subsequently exert cytotoxic and cytostatic actions on hepatoma cells via an NO-dependent mechanism (Fig. 9). This scenario is supported by the previous report from Goodrum et al. (7) which shows that CD11b/CD18 mediates the bacteria-induced NO production in murine macrophages, and is further supported by

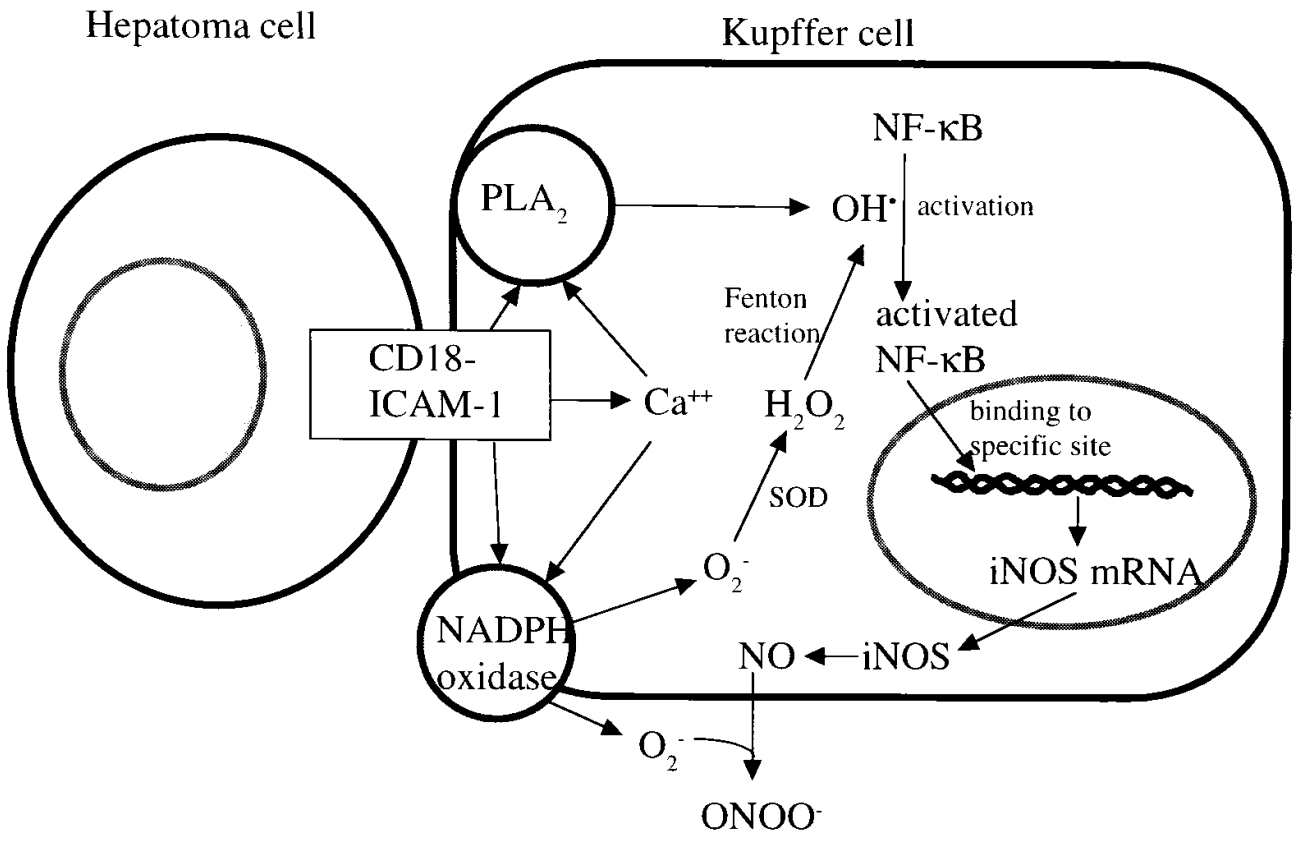

Figure 9. Schematic representation of possible mechanisms involved in NO production of Kupffer cells. $S O D$, superoxide dismutase; $P L A_{2}$, phospholipase $\mathrm{A}_{2}$. 
other studies which indicate that integrins are the primary signal transduction molecules regulating selective mRNA expression (39-44).

Initiation of mRNA synthesis is a primary control point in the regulation of gene expression. Systematic mutational analysis revealed that each gene has a particular arrangement of positive and negative regulatory elements uniquely arranged as to type, number, and spatial array. In response to specific environmental stimuli, the activated transcription factor binds to a specific DNA sequence and confers the ability upon the target gene to synthesize mRNA. One of the major inducible transcription factors which is activated in a variety of re-

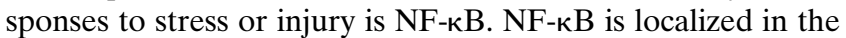
cytoplasm in an inactive form where it is asociated with an inhibitor protein, IкB. The inhibitor retains the NF-кB complex in the cytoplasm and inhibits DNA binding. The various $\mathrm{NF}-\mathrm{B}$ activators cause an alteration of $\mathrm{I} \kappa \mathrm{B}$, possibly phosphorylation, allowing $\mathrm{NF}-\kappa \mathrm{B}$ to be released from the complex. NF-кB then moves to the nucleus, where it binds to the DNA recognition site and mediates gene transcription.

The fluorescence DNA-protein binding assay used in this study is based on the nature of NF-кB. The FITC-labeled oligodeoxynucleotides comprising specific NF- $\mathrm{B}$ binding sites of iNOS promoter can bind to only activated NF-кB in mainly cytosol and in part nucleus. Then, the bound FITC-labeled oligonucleotides move into the nucleus according to the movement of activated NF- $\mathrm{B}$, which can be shown as an accumulation of FITC fluorescence in nuclei under the laser scanning confocal microscope. Thus, the DNA-binding activity of NF- $\mathrm{BB}$ in cultured cells was detected by this method, and the number of Kupffer cells in which nucleus is positively stained with FITC was calculated as an indicator of NF- $\mathrm{KB}$ activation in Kupffer cells after the coculture with AH70 cells. The results obtained from this assay clearly revealed that FITC fluorescence can be visualized in nucleus of Kupffer cell which adhered to AH70 cells, and the number of FITC-positive Kupffer cells significantly increases after the coculture with AH70 cells. Therefore, it is possible that adhesive interaction with AH70 cells activates Kupffer cell NF-кB which is known to regulate transcription of iNOS and mRNA $(11,12)$. Attenuating effect of treatment with mAb against CD18 and ICAM-1 suggests that adhesive interaction which causes NF-кB activation largely depends on CD18/ICAM-1 (Fig. 9).

In some cell types, hydrogen peroxide or depletion of glutathione levels rapidly activates $\mathrm{NF}-\kappa \mathrm{B}$; antioxidants inhibit $\mathrm{NF}-\kappa \mathrm{B}$ activation. Thus, the presence of reactive oxygen intermediates correlates directly with the activation state of NF- $\mathrm{B}$. $\mathrm{NF}-\kappa \mathrm{B}$ is sensitive to redox changes in vitro; however, general oxidation of the transcription factor inactivates the complex (45). This suggests that the activity of the factor is selectively modified by a specific mechanism and not regulated by the general cellular redox potential. Based on these observations, models have been proposed in which generation of reactive oxygen intermediates dissociates the inactive cytoplasmic NF$\kappa \mathrm{B}$. The active form of NF-кB migrates to the nucleus where it binds cognate recognition elements and specifically activates transcription. Therefore, the oxidative stress was monitored in cultured cells by using oxygen-sensitive fluorescence probe DCFH-DA. The fluorescence of DCF which is the oxidized form of DCFH initially (within $10 \mathrm{~min}$ ) increased in Kupffer cells adhered to AH70 cells, suggesting the production of oxygen radicals. The increase in DCF fluorescence was effectively attenuated by DMTU and PDTC, both of which are cell membrane-permeable antioxidants. Incubation with mAbs directed against CD18 and ICAM-1 also prevented the DCF activation in Kupffer cells cocultured with AH70 cells. Furthermore, the increases in NF- $\mathrm{KB}$ activation and NO production in Kupffer cells cocultured with AH70 cells were also prevented by the addition of either one of these agents. Therefore, it is concluded that CD18/ICAM-1-dependent oxyradical production may lead to NF- $\mathrm{BB}$ activation and NO production in Kupffer cells. Attenuating effects of DMTU, a hydrogen peroxide scavenger, and PDTC, an inhibitor of oxidative NF- $\mathrm{B}$ activation, on increases in DNA-protein binding-positive Kupffer cells and NO production strongly suggest the occurrence of oxidative activation of NF- $\mathrm{BB}$ leading to NO production in Kupffer cells.

We further investigated the source of oxygen radicals which activate Kupffer cell NF-кB after the coculture with AH70 cells. DPI, an NADPH oxidase inhibitor, as well as quinacrine, a phospholipase $\mathrm{A}_{2}$ inhibitor, effectively attenuated increases in DCF fluorescence and NO production of Kupffer cells and the number of DNA-protein binding assaypositive Kupffer cells observed after the coculture with AH70 cells, whereas these agents did not alter the fluo-3 fluorescence. Inhibitory effects of these agents suggest that NADPH oxidase and phospholipase $\mathrm{A}_{2}$ contribute to oxidative NF-кB activation leading to NO production of Kupffer cells in response to CD18/ICAM-1-dependent adherence to AH70 cells. However, the present results do not eliminate an involvement of other oxygen radical sources such as xanthine oxidase and calcium-independent phospholipase $\mathrm{A}_{2}$. Therefore, further detailed examinations are required to evaluate major oxygen sources for NF-кB activation in Kupffer cells.

Another important evidence provided by this study is the involvement of calcium in the proess for oxidative activation of $\mathrm{NF}-\kappa \mathrm{B}$ and NO production of Kupffer cells. Investigations using fluo-3 clearly revealed that inhibition of CD18 and ICAM1-dependent adhesive interaction with AH70 cells by the treatment with specific monoclonal antibodies significantly attenuates calcium mobilization in Kupffer cells after the coculture. Attenuating effects of TMB- 8 on fluo-3 fluorescence, DCF fluorescence, DNA-protein binding assay, and NO production of Kupffer cells cocultured with AH70 cells support a scenario that calcium mobilization leads to oxyradical generation, oxidative NF- $\mathrm{BB}$ activation, and NO production of Kupffer cells. This scenario was further supported by the present results that calcium ionophore A23187 increased fluo-3 and DCF fluorescences and NO production of Kupffer cells and the number of DNA-protein binding assay-positive Kupffer cells. Taken together, this study suggests that CD18/ICAM-1-dependent adhesive interaction with hepatoma cells stimulates calcium mobilization and subsequent oxyradical-mediated NF-кB activation which leads to transcription of iNOS mRNA, iNOS induction, and NO production of Kupffer cells.

In our present experimental model using coculture system of rat Kupffer cells and AH70 cells, we have reported that Kupffer cell-derived NO also induces mitochondrial dysfunction $(9,10)$ and apoptosis $(46)$ of hepatoma cells in vitro. We further demonstrated that the NO-dependent cell injury may occur in ex vivo model using isolated-perfused rat liver, in which AH70 cells are infused from the portal vein (47). Stadler et al. (48) and we (26) have reported that NO released from LPS-activated Kupffer cells causes mitochondrial dysfunction in cocultured hepatocytes. We further reported that it can be 
seen in isolated-perfused rat liver (26). However, Fisch et al. (49) reported recently that the NO-dependent hepatocyte injury cannot be produced in the liver subjected to LPS infusion in vivo, because there are inhibitors and scavenging system such as hemoglobin. In addition, the endothelial cells exist between Kupffer cells and hepatocytes and may interrupt NO released from Kupffer cells. In contrast to the hepatocyte injury by LPS-activated Kupffer cells, NO production and release by Kupffer cells cocultured with hepatoma cells requires firm adherence via CD18 and ICAM-1, and it can be observed within the narrow sinusoidal lumen. In such a case, NO released from Kupffer cells may directly get into hepatoma cells without interacting with extracellular scavengers. Therefore, it is possible that NO released from Kupffer cells plays a cytotoxic role by inducing mitochondrial dysfunction and apoptosis of hepatoma cells not only in vitro but also in vivo.

\section{Acknowledgments}

The authors thank the Japanese Cancer Research Bank for donating rat hepatoma cell line, AH70 cells. Stimulating discussions with Dr. Toshio Nakaki, Department of Pharmacology, Teikyo University School of Medicine, are gratefully acknowledged.

This study was supported by a Grant-in-Aid for Scientific Research from the Japanese Ministry of Education, Science and Culture of Japan, and by a grant from Keio University, School of Medicine. I. Kurose received a Searl Scientific Research Fellowship in 1996.

\section{References}

1. Keller, R., M. Geiges, and R. Keist. 1990. L-Arginine-dependent reactive nitrogen intermediates as mediators of tumor killing by activated macrophages. Cancer Res. 50:1421-1425.

2. Hibbs, J.B., Jr., Z. Vavrin, and R.R. Taintor. 1987. L-Arginine is required for expression of the activated macrophage effector mechanism causing selective metabolic inhibition in target cells. J. Immunol. 138:550-565.

3. Nathan, C.F., L.H. Brukner, S.C. Silverstein, and Z.A. Cohn. 1979. Extracellular cytolysis by activated macrophages and granulocytes. I. Pharmacologic triggering of effector cells and the release of hydrogen peroxide $J$. Exp. Med. 148:84-99.

4. Adams, D.O., W.J. Johnson, and P.A. Marino. 1982. Mechanisms of target recognition and destruction in macrophage-mediated tumor cytotoxicity. Fed. Proc. 41:2212-2221.

5. Adams, D.O., and C.F. Nathan. 1983. Molecular mechanisms in tumorcell killing by activated macrophages. Immunol. Today. 4:166-170.

6. Latocha, G., P. Dieter, A. Schulze-Speacking, and K. Decker. 1989. Fc receptors mediate prostaglandin and superoxide synthesis in cultured rat Kupffer cells. Biol. Chem. Hoppe-Seyler. 370:1055-1061.

7. Goodrum, K.J., L.L. McCormick, and B. Schneider. 1994. Group B streptococcus-induced nitric oxide production in murine macrophages is $\mathrm{CR}$ (CD11b/CD18) dependent. Infect. Immun. 62:3102-3107.

8. Bouwens, L., M. Baekeland, R. De Zanger, and E. Wisse. 1986. Quantitation, tissue distribution and proliferation kinetics of Kupffer cells in normal rat liver. Hepatology. 6:718-722.

9. Kurose, I., S. Miura, D. Fukumura, Y. Yonei, H. Saito, S. Tada, M. Suematsu, and M. Tsuchiya. 1993. Nitric oxide mediates Kupffer cell-induced reduction of mitochondrial energization in syngeneic hepatoma cells: a comparison with oxidative burst. Cancer Res. 53:2676-2682.

10. Kurose, I., H. Ebinuma, H. Higuchi, Y. Yonei, H. Saito, S. Kato, S. Miura, and H. Ishii. 1995. Nitric oxide mediates mitochondrial dysfunction in hepatoma cells induced by non-activated Kupffer cells: an evidence implicating ICAM-1-dependent process. J. Gastroenterol. Hepatol. 10:S68-S71.

11. Xie, Q.-W., Y. Kashiwabara, and C. Nathan. 1994. Role of transcriptional factor NF- $\mathrm{B} / \mathrm{Rel}$ in induction of nitric oxide synthase. J. Biol. Chem. 269:4705-4708.

12. Xie, Q.-W., R. Whisnant, and C. Nathan. 1993. Promoter of the mouse gene encoding calcium-independent nitric oxide synthase confers inducibility by interferon $\gamma$ and bacterial lipopolysaccharide. J. Exp. Med. 177:1779-1784.

13. Schreck, R., P. Rieber, and P.A. Baeuerle. 1991. Reactive oxygen intermediates as apparently widely used second messengers in the activation of the NF-кB transcription factor and HIV-1. EMBO (Eur. Mol. Biol. Organ.) J. 10: 2247-2258.

14. Staal, F.J.T., M. Roederer, and L.A. Herzenberg. 1990. Intracellular thi- ols regulate activation of nuclear factor $\mathrm{\kappa B}$ and transcription of human immunodeficiency virus. Proc. Natl. Acad. Sci. USA. 87:9943-9947.

15. Mihm, S., J. Ennen, U. Pessara, R. Kurth, and W. Dröge. 1991. Inhibition of HIV-1 replication and NF- $\mathrm{B}$ activity by cysteine and cysteine derivatives. AIDS (Phila.). 5:497-503.

16. Perchellet, E.M., E.A. Matta, and N.L. Abney. 1987. Effects of diverse intracellular thiol delivery agents on glutathione peroxidase activity, the ratio of reduced/oxidized glutathione, and ornithine decarboxylase induction in isolated mouse epidermal cells treated with 12 - $O$-tetradecanoyl-phorbol-13-acetate. J. Cell. Physiol. 131:64-73.

17. Sando, J.J., M.L. Hilfiker, D.S. Salomon, and J.J. Farrar. 1981. Specific receptors for phorbol esters in lymphoid cell populations: role in enhanced production of T-cell growth factor. Proc. Natl. Acad. Sci. USA. 78:1189-1193.

18. Fischer, S.M., and L.M. Adams. 1985. Suppression of tumor promoterinduced chemiluminescence in mouse epidermal cells by several inhibitors of arachidonic acid metabolism. Cancer Res. 45:3130-3136.

19. Bonser, R.W., J. Dawson, N.T.Thompson, H.F. Hodson, and L.G. Garland. 1986. Inhibition of phorbol ester stimulated superoxide production by 1-oleoyl-2-acetyl-sn-glycerol (OAG); fact or artefact? FEBS Lett. 209:134-138.

20. Meier, B., H.H. Radeke, S. Selle, M. Younes, H. Sies, K. Resch, and G.G. Habermehl. 1989. Human fibroblasts release reactive oxygen species in response to interleukin-1 or tumor necrosis factor- $\alpha$. Biochem. J. 263:539-545.

21. Meier, B., H.H. Radeke, S. Selle, G.G. Habermehl, K. Resch, and H. Sies. 1990. Human fibroblasts release low amounts of reactive oxygen intermediates in response to the potent phagocyte stimulants, serum-treated zymosan $\mathrm{N}$-formyl-methionyl-leucyl-phenylalanine, leukotriene B4 or 12-o-tetradecoylphorbol 13-acetate. Biol. Chem. Hoppe-Seyler. 371:1021-1025.

22. Schreck, R., and P.A. Baeuerle. 1991. A role for oxygen radicals as second messengers. Trends Cell Biol. 1:39-48.

23. Shappell, S.B., C. Toman, D.C. Anderson, A.A. Taylor, M.L. Entman, and C.W. Smith. 1990. Mac-1 (CD11B/CD18) mediates adherence-dependen hydrogen peroxide production by human and canine neutrophils. J. Immunol. 144:2702-2711.

24. Baeuerle, P.A. 1991. The inducible transcription activator NF-кB: regulation by distinct protein subunits. Biochim. Biophys. Acta. 1072:63-80.

25. Richter, J., J. Ng-Sikorski, I. Olsson, and T. Andersson. 1990. Tumor necrosis factor-induced degranulation in adherent human neutrophils is dependent on CD11b/CD18-integrin-triggered oscillations of cytosolic free $\mathrm{Ca}^{2+}$. Proc. Natl. Acad. Sci. USA. 87:9472-9476.

26. Kurose, I., S. Kato, H. Ishii, D. Fukumura, S. Miura, M. Suematsu, and M. Tsuchiya. 1993. Nitric oxide mediates lipopolysaccharide-induced alteration of mitochondrial function in cultured hepatocytes and isolated perfused liver. Hepatology. 18:380-388.

27. Kurose, I., R. Wolf, M.B. Grisham, and D.N. Granger. 1994. Modulation of ischemia/reperfusion-induced microvascular dysfunction by nitric oxide. Circ. Res. 74:376-382.

28. Granger, D.L., J.B. Hibbs, Jr., J.R. Perfect, and D.T. Durack. 1990. Metabolic fate of L-arginine in relation to microbiostatic capability of murine macrophages. J. Clin. Invest. 85:264-273.

29. Eberhard, M., and P. Erne. 1989. Kinetics of calcium binding to fluo-3 determined by stopped-flow fluorescence. Biochem. Biophys. Res. Commun. 163:309-314.

30. Merrit, J.E., S.A. McCarthy, M.P.A. Davies, and K.E. Moores. 1990. Use of fluo-3 to measure cytosolic $\mathrm{Ca}^{2+}$ in platelets and neutrophils. Biochem. J. 269:513-519.

31. Cathcart, R., E. Schwiers, and B.N. Ames. 1983. Detection of picomole levels of hydroperoxides using a fluorescent dichlorofluorescein assay. Anal. Biochem. 134:111-116.

32. Schreck, R., B. Meier, D.N. Männel, W. Dröge, and P.A. Baeuerle. 1992. Dithiocarbamates as potent inhibitors of nuclear factor $\mathrm{\kappa B}$ activation in intact cells. J. Exp. Med. 175:1181-1194.

33. Fox, R.B. 1984. Prevention of granulocyte-mediated oxidant lung injury in rats by a hydroxyl radical scavenger, dimethylthiourea. J. Clin. Invest. 74: 1456-1464.

34. Jackson, J.H., C.W. White, N.B. Parker, J.W. Ryan, and J.E. Repine. 1985. Dimethylthiourea consumption reflects $\mathrm{H}_{2} \mathrm{O}_{2}$ concentrations and severity of acute lung injury. J. Appl. Physiol. 59:1995-1998.

35. Schreck, R., K. Albermann, and P.A. Baeuerle. 1992. Nuclear factor $\kappa$ B an oxidative stress-responsive transcription factor of eukaryotic cells (a review). Free Rad. Res. Commun. 17:221-237.

36. Griffiths, M.J.D., M. Messent, R.J. MacAllister, and T.W. Evans. 1993. Aminoguanidine selectively inhibits inducible nitric oxide synthase. Br. J. Pharmacol. 110:963-968.

37. Hasan, K., B.-J. Heesen, J.A. Corbett, M.L. McDaniel, K. Chang, W. Allison, B.H.R. Wolffenbuttel, J.R. Williamson, and R.G. Tilton. 1993. Inhibition of nitric oxide formation by guanidines. Eur. J. Pharmacol. 249:101-106.

38. Yonei, Y., I. Kurose, D. Fukumura, S. Saito, S. Miura, N. Tsukada, M. Oda, and M. Tsuchiya. 1994. Evidence of direct interaction between Kupffer cells and colon cancer cells: an ultrastructural study of the co-culture. Liver. 14: $37-44$.

39. Rosales, C., and R. Juliano. 1996. Integrin signaling to NF-кB in monocytic leukemia cells is blocked by activated oncogenes. Cancer Res. 56:2302- 
2305 .

40. Haskill, S., A.A. Beg. S.M. Tompkins, J.S. Morris, A.D. Yurochko. A. Sampson-Johannes, K. Mondal, P. Ralph, and A.S.J. Baldwin. 1991. Characterization of an immediate-early gene induced in adherent monocytes that encodes IкB-like activity. Cell. 65:1281-1289.

41. Haskill, S., C. Johnson, D. Eierman, S. Haskill, and K. Warren. 1988. Adherence induces selective mRNA expression of monocyte mediators and proto-oncogenes. J. Immunol. 140:1690-1694.

42. Yurochko, A.D., D.Y. Liu, D. Eierman, and S. Haskill. 1992. Integrins as a primary signal transduction molecule regulating monocyte immediate-early gene induction. Proc. Natl. Acad. Sci. USA. 89:9034-9038.

43. Lin, T.H., A. Yurochko, L. Kornberg, J. Morris, J.J. Walker, S. Haskill, and R.L. Juliano. 1994. The role of protein tyrosine phosphorylation in integrin-mediated gene induction in monocytes. J. Cell Biol. 126:1585-1593.

44. Lin, T.H., C. Rosales, K. Mondal, J.B. Bolen, S. Haskill, and R.L. Juliano. 1995. Integrin-mediated tyrosine phosphorylation and cytokine message induction in a monocytic cell line: a possible signaling role for the Syk tyrosine kinase. J. Biol. Chem. 270:16189-16197.
45. Toledano, M.D., and W.J. Leonard. 1991. Modulation of transcription factor NF-кB binding activity by oxidation-reduction in vitro. Proc. Natl. Acad. Sci. USA. 88:4328-4332.

46. Kurose, I., H. Higuchi, Y. Yonei, H. Ebinuma, N. Watanabe, R. Hokari, D. Fukumura, S. Miura, M. Takaishi, H. Saito, et al. 1996. Rat Kupffer cellderived nitric oxide suppresses proliferation and induces apoptosis of syngeneic hepatoma cells. Gastroenterology. 111:1058-1070.

47. Fukumura, D., Y. Yonei, I. Kurose, H. Saito, T. Ohishi, H. Higuchi, S Miura, S. Kato, H. Kimura, H. Ebinuma, and H. Ishii. 1996. Role of nitric oxide in Kupffer cell-mediated hepatoma cell cytotoxicity in vitro and ex vivo. Hepatology. 24:141-149.

48. Stadler, J., T.R. Billiar, R.F. Curran, D.J. Stuehr, J.B. Ochoa, and R.L. Simmons. 1991. Effects of authentic and cell-generated nitric oxide on mitochondrial respiration of rat hepatocytes. Am. J. Physiol. 260:C910-C916.

49. Fisch, C., M.A. Robin, P. Letteron, B. Fromenty, A. Berson, S. Renault, C. Chachaty, and D. Pessayre. 1996. Cell-generated nitric oxide inactivates rat hepatocyte mitochondria in vitro but reacts with hemoglobin in vivo. Gastroenterology. 110:210-220. 